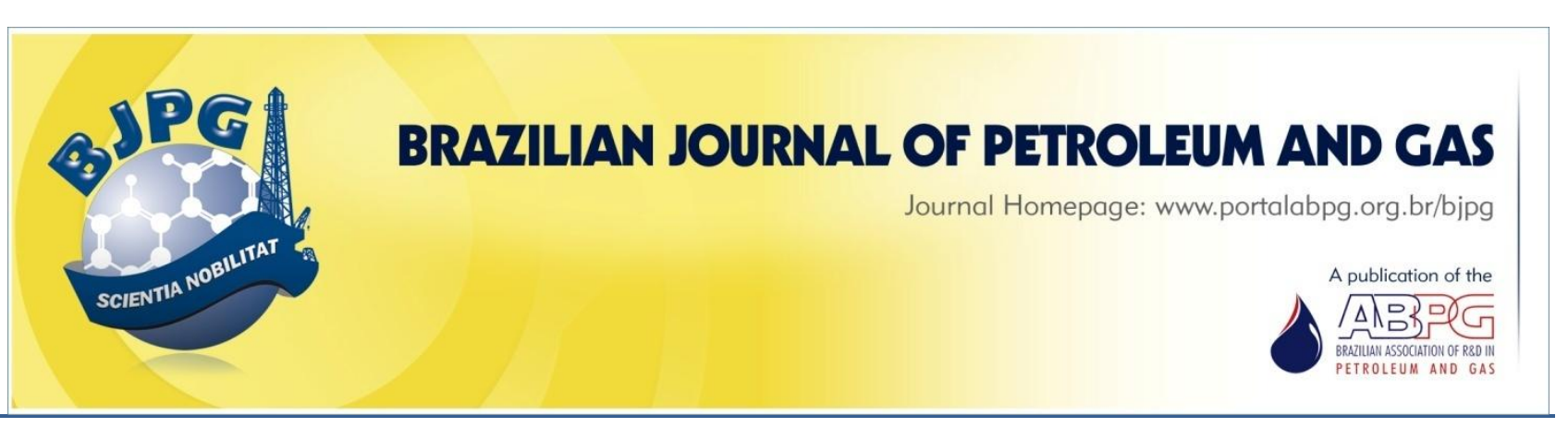

\title{
THE USE OF PRODUCED WATER IN WATER-BASED DRILLING FLUIDS: INFLUENCE OF CALCIUM AND MAGNESIUM CONCENTRATIONS
}

\author{
${ }^{a}$ Ribeiro, L. S.; ${ }^{a}$ Dantas, T. N. C $^{1}$; ${ }^{\text {a,b }}$ Dantas Neto, A. A.; Melo, ${ }^{\text {c }}$ K. C.; \\ a,b Moura, M. C. P. A.; ${ }^{d}$ Aum, P. T. P.
}

\footnotetext{
${ }^{a}$ Programa de Pós-Graduação em Engenharia Química, Universidade Federal do Rio Grande do Norte, Natal-RN, Brasil

${ }^{b}$ Programa de Pós-Graduação em Engenharia de Petróleo e gás Natural - Universidade Potiguar, Natal-RN, Brasil

${ }^{c}$ Instituto Federal de Educação, Ciência e Tecnologia do Rio Grande do Norte, Natal-RN, Brasil

d Programa de Pós-Graduação em Ciência e Engenharia de Petróleo, Universidade Federal do Rio Grande do Norte, NatalRN, Brasil
}

Received: 11.10.2016 / Revised: 06.12.2016 / Accepted: 06.12.2016 / Published on line: 29.12.2016

\begin{abstract}
The Urucu oilfield (Amazon Basin, Brazil) has a large volume of produced water with a high concentration of salts. The treatment and disposal of its produced water are very difficult, justifying its reuse. In this work, synthetic produced waters, with different concentrations of calcium and magnesium salts, are used in the formulation of water-based drilling fluids. A full $3^{2}$ factorial design is applied to evaluate the influence of these salts on fluid rheology and filtrate. Magnesium concentration did not influence the properties of the fluid, but higher concentrations of calcium $(43.63 \mathrm{~g} / \mathrm{L})$ caused undesirable outcomes, including the presence of precipitate, high volume of filtrate, thick cake formation, and rheological properties with low power of carrying gravels. The high content of sodium in the produced water eliminated the need of adding $\mathrm{NaCl}$ to drilling fluid, making the developed fluid less expensive. The best composition was obtained using produced water with maximum magnesium concentration $(9.411 \mathrm{~g} / \mathrm{L})$ and minimum calcium concentration $(0.733 \mathrm{~g} / \mathrm{L})$.
\end{abstract}

\section{KEYWORDS}

drilling fluid; produced water; rheology; API filter; calcium; magnesium

\footnotetext{
${ }^{1}$ To whom all correspondence should be addressed.

Address: Programa de Pós-Graduação em Engenharia Química, Universidade Federal do Rio Grande do Norte, Lagoa Nova, Natal - RN - Brasil | ZIP Code: 59078-970 | Phone/Fax : +55(84)3215-3773/+55(84) 3215-3827 |e-mail: tereza@eq.ufrn.br; terezaneuma1011@yahoo.com.br doi:10.5419/bjpg2016-0019
} 


\section{INTRODUCTION}

According to the American Petroleum Institute (API), drilling fluid is a circulating fluid used during rotary drilling operations (Fink, 2012). It can be called "boreholes blood" for maintaining a properly functioning well. It is also called slurry or mud, and it flows through the drill string, spraying out of nozzles on the drill bit. The main functions of a drilling fluid are: to drag the drill cuttings to the surface; to control formation pressure; to cool and lubricate the drill; and to "seal" permeable formations, maintaining the stability of the well (Vajargah et al., 2015; Zhuang et al., 2015).

Drilling fluids are classified according to their base as water-based, oil-based, or air-based. Water is the continuous phase in water-based fluids (Caenn et al., 2011). Oil-based fluids have excellent properties, such as stability and lubricity. However, the use of such fluids can cause damage to the environment (Meng et al., 2012). The use of waterbased fluids has increased in oil and gas exploration because they are considered environmentally acceptable in relation to the use of non-aqueous ones (El-Sukkary et al., 2014).

The base of a water-based fluid can be fresh water, salt water, brine, or saline solution. It may contain several dissolved substances, including: alkalis, salts, surfactants, organic polymers in colloidal form, emulsified oil droplets, and insoluble substances such as barite and clay. The type of fluid chosen in drilling operations depends on the formation and the region to be drilled (Fink, 2012; Lake, 2006). Drilling fluids represent one of the largest expenses of the drilling process. To minimize its costs and ensure efficient drilling, fluid properties must be monitored and maintained during operations, being essential to control rheological properties, density, API filter, solid and liquid content, $\mathrm{pH}$, chloride content, and fluid hardness (Caenn et al., 1996; Menezes et al., 2010; Nasser et al., 2013).

Produced water is the largest waste of the oil industry and, generally, it contains high levels of heavy metals, organic compounds, and other toxic elements added during oil production. Wastewater may cause a negative environmental impact if improperly discarded (Rocha et al., 2012). Currently, it can be treated to remove dispersed oil, organic matter, suspended particulates, gases, carbon dioxide, hydrogen sulfide, toxic contaminants, and dissolved salts. After treatment, it can be used for injection in secondary recovery wells, discharged into surface water bodies, applied in oil and gas drilling operations, used in irrigation systems, and even for feeding animals and humans (Fakhru'l-Razi et al., 2009).

Considering that produced water is an oilfield waste, Fakhru'l-Razi et al. (2009) suggested a three-step management to prevent environmental pollution. First, it is necessary to employ advanced technologies to reduce its production. Second, it should be reused or recycled. Finally, if neither of the previous steps are practical, it should be disposed of properly. Zeng et al. (2016) evaluated treatment technologies for the Arctic offshore produced waters. They observed that centrifuges are more efficient in the removal of small oil droplets than hydrocyclones, but require higher energy and maintenance costs. They also evaluated physical filtration systems using sand and nutshells, treatments by membrane techniques, adsorption, and chemical oxidation, among others. However, each of these treatments had some pros and cons and it was still necessary to develop a more mature regulatory system to meet the needs of production in harsh environments. Riley et al. (2016) evaluated the pre-treatment of produced water and fracturing flowback wastewater using biologically active filter (BAF). The use of this technology before ultrafiltration and nanofiltration membrane technologies reduced problems related to membrane fouling. The authors observed that, with full treatment, more than $99 \%$ organic constituents and more than $94 \%$ total solid dissolved may be removed, producing water that can be used in several applications, including livestock watering, aquifer recharge, hydraulic fracturing, and other industrial applications.

The produced water from the Urucu oilfield (Amazon basin - Brazil) is considered a problem due to its high volume, the difficulties in promoting onsite treatment and disposal, and the presence of high concentrations of calcium and magnesium chlorides and organic compounds in its composition. Due to environmental concerns, water-based drilling fluids are used in drilling operations in this oilfield. Based on the exposed, this work aims to use synthetic produced water in the formulation of these fluids, observing the influence of calcium and magnesium 
concentrations in its rheological behavior and filtrate properties.

\section{MATERIALS AND METHODS}

\subsection{Synthetic produced water}

According to Sharghi et al. (2014), synthetic produced water was synthesized. The chemicals and concentrations shown in Table 1 were used in the process. First, the salts were added to one liter of distilled water to prepare the brine.
Subsequently, this brine was stirred at $27,000 \mathrm{rpm}$ (3 min) with a Turratec mechanical stirrer (TECNAL, Mod. TE-102) and the oil (1g/L) was added dropwise during 3 minutes. Table 2 shows that its composition was based on real wastewater from Petrobras Urucu Oilfield (Amazon basin - Brazil). The concentration values shown in Table 1 were calculated considering the molecular mass of each compound. For example, in the mass of $\mathrm{MgCl}_{2} \cdot 6 \mathrm{H}_{2} \mathrm{O}$ weighted one has $11.95 \% \mathrm{Mg}(1.12 \mathrm{~g} / \mathrm{L}$ $\mathrm{Mg}$ ) and for $\mathrm{CaCl}_{2} .2 \mathrm{H}_{2} \mathrm{O}$ one has $27.26 \% \mathrm{Ca}$ $(11.89 \mathrm{~g} / \mathrm{L} \mathrm{Ca})$.

Table 1. Materials and concentration of salts and oil used to formulate synthetic produced water.

\begin{tabular}{|c|c|c|c|c|}
\hline Material & Molecular Formula & $\begin{array}{c}\text { Concentration } \\
(\mathrm{g} / \mathrm{L})\end{array}$ & Origin & $\begin{array}{c}\text { Purity } \\
(\%)\end{array}$ \\
\hline Potassium sulphate & $\mathrm{K}_{2} \mathrm{SO}_{4}$ & 1.81 & $\begin{array}{c}\text { Êxodo } \\
\text { Científica }\end{array}$ & 99.0 \\
\hline Magnesium chloride hexahydrate & $\mathrm{MgCl}_{2} \cdot 6 \mathrm{H}_{2} \mathrm{O}$ & 9.41 & NEON & 99.6 \\
\hline Calcium chloride & $\mathrm{CaCl}_{2} \cdot 2 \mathrm{H}_{2} \mathrm{O}$ & 43.64 & $\begin{array}{c}\text { Êxodo } \\
\text { Científica }\end{array}$ & 99.0 \\
\hline Lithium sulfate & $\mathrm{Li}_{2} \mathrm{SO}_{4} \cdot \mathrm{H}_{2} \mathrm{O}$ & 0.27 & $\begin{array}{c}\text { Êxodo } \\
\text { Científica }\end{array}$ & 99.0 \\
\hline Sodium Chloride & $\mathrm{NaCl}$ & 91.43 & $\begin{array}{c}\text { Êxodo } \\
\text { Científica }\end{array}$ & 99.0 \\
\hline Oil & - & 1.00 & $\mathrm{BR}$ & - \\
\hline Distilled water & $\mathrm{H}_{2} \mathrm{O}$ & - & - & - \\
\hline
\end{tabular}

Table 2. Concentration of oil and metals from Urucu's produced water.

\begin{tabular}{ccc}
\hline Constituent & Unit & Ururu-AM \\
\hline Acetate & $\mathrm{g} / \mathrm{L}$ & 0.0172 \\
Bromide & $\mathrm{g} / \mathrm{L}$ & 0.416 \\
Chloride & $\mathrm{g} / \mathrm{L}$ & 95.983 \\
Total Fluoride & $\mathrm{g} / \mathrm{L}$ & 0.0004 \\
Formate & $\mathrm{g} / \mathrm{L}$ & 0.001 \\
Nitrate & $\mathrm{g} / \mathrm{L}$ & 0.134 \\
Total sulphate & $\mathrm{g} / \mathrm{L}$ & 0.196 \\
Total Barium & $\mathrm{g} / \mathrm{L}$ & $<\mathrm{DL}$ \\
Calcium & $\mathrm{g} / \mathrm{L}$ & 11.90 \\
Strontium & $\mathrm{g} / \mathrm{L}$ & 0.37 \\
Iron & $\mathrm{g} / \mathrm{L}$ & - \\
Total lithium & $\mathrm{g} / \mathrm{L}$ & 0.02 \\
Magnesium & $\mathrm{g} / \mathrm{L}$ & 1.12 \\
Potassium & $\mathrm{g} / \mathrm{L}$ & 0.81 \\
Sodium & $\mathrm{g} / \mathrm{L}$ & 35.96 \\
Total oils and & $\mathrm{g} / \mathrm{L}$ & $<\mathrm{DL}$ \\
grease & & \\
\hline
\end{tabular}


Table 3. Materials added to $350 \mathrm{~mL}$ of produced water to formulate the polymeric salt water-based drilling fluid.

\begin{tabular}{lcc}
\hline \multicolumn{1}{c}{ Product } & Concentration (lb/bbl) & Stirring time (min) \\
\hline Calcium remover & 0.5 & Until total solubilization \\
Viscosifier (Xanthan Gum) & 0.5 & 60 \\
Alkalinity/ pH controller & 0.5 & Until total solubilization \\
$\begin{array}{l}\text { Coagulant [PACL (polyaluminum } \\
\text { chloride) }\end{array}$ & 0.5 & 60 \\
Filtrate controller [HPA (polyaromatic & 3.0 & 60 \\
hydrocarbons)] & & \\
Filtrate controller [CMC ADS & 2.0 & 60 \\
(carboxymethyl celulose)] & & \\
Thickening agent 1 / clay suppressor & 17.0 & Until total solubilization \\
[NaCl (Sodium chloride)] & & Until total solubilization \\
Bridging agent 1 & 20.0 & Until total solubilization \\
Bridging agent 2 & 20.0 & Until total solubilization \\
Thickener agent 2 & 20.0 & Until total solubilization \\
Bactericide & 0.5 & 30 \\
Clay inhibitor & 10.0 & \\
\hline
\end{tabular}

\subsection{Drilling fluid preparation}

The water-based drilling fluid was formulated using $350 \mathrm{~mL}$ of synthetic produced water and additives. Table 3 describes the order addition, concentration, and stirring time used in the experiment. A Hamilton Beach mechanical stirrer was used in this step (FANN, Mod. HMD200).

\subsection{Determination of water-based drilling fluid properties}

All procedures to determine the properties of the drilling fluid were performed according to the American Petroleum Institute guidelines (API, 1990).

\subsubsection{Density and rheology}

The density of the fluid was obtained using a mud balance (Fann, Model 140). Shear stress, plastic viscosity (PV), apparent viscosity (AV), yield point (Yp), and gel strength parameters (initial 10seconds and final 10-minutes) were determined using a rotary viscometer (Fann, Model 35). The thixotropic properties were also considered. The 6speed rotational viscometer read the viscosity values at different speeds $600 \mathrm{rpm}, 300 \mathrm{rpm}$, $200 \mathrm{rpm}, 100 \mathrm{rpm}, 6 \mathrm{rpm}$, and $3 \mathrm{rpm}$ ). Initial and final gel strengths were obtained according to the American Petroleum Institute Guidelines (API, 1990). Plastic viscosity, apparent viscosity, and yield point were calculated according to Equations (1), (2), and (3) (AMOCO, 1994).

$\mathrm{PV}, \mathrm{cP}=$ (600rpm dial Reading) -

- (300rpm dial Reading)

$\mathrm{AV}, \mathrm{cP}=0.5 *(600 \mathrm{rpm}$ dial Reading $)$

YP, $\mathrm{lb} / 100 f t^{2}=$

$=(300 \mathrm{rpm}$ dial Reading $)-(\mathrm{PV})$

\subsubsection{Filtration, retort, $\mathrm{pH}$, and ageing properties}

To determine the API filtration, at low pressure and temperature, an API filter press (Fann API series 300, LPLT) was used. The test was performed at 100 psi, for 30 minutes. At the end of the test, filtrate volume and cake thickness were measured. The retort test was used to determine the percentage of the liquid phase (vol. \% water and vol. \% oil) collected after the distillation of a known volume of fluid. The retort solids were calculated subtracting the volume of the collected liquid phase from the total volume of fluid used in the test (API, 1990). The $\mathrm{pH}$ test was performed with the aid of a pH indicator paper. For the dynamic ageing study, ageing cells with water-based drilling fluids were placed in a roller oven (Fann, model $704 \mathrm{ET})$, and agitated by rolling the cells during $16 \mathrm{~h}$, at $65^{\circ} \mathrm{C}$. 
Table 4. Encoded matrix with factors levels and concentrations of calcium and magnesium in the synthetic produced waters for each experimental run.

\begin{tabular}{ccccc}
\hline Sample & {$[\mathrm{Mg}](\mathrm{g} / \mathrm{L})$} & {$[\mathrm{Ca}](\mathrm{g} / \mathrm{L})$} & {$[\mathrm{Mg}](\mathrm{g} / \mathrm{L})$} & {$[\mathrm{Ca}](\mathrm{g} / \mathrm{L})$} \\
\hline 1 & -1 & 0 & 0.209 & 22.186 \\
2 & 0 & -1 & 4.810 & 0.733 \\
3 & +1 & 0 & 9.411 & 22.186 \\
4 & -1 & -1 & 0.209 & 0.733 \\
5 & -1 & +1 & 0.209 & 43.630 \\
6 & +1 & -1 & 9.411 & 0.733 \\
7 & 0 & 0 & 4.810 & 22.186 \\
8 & 0 & +1 & 4.810 & 43.630 \\
9 & +1 & +1 & 9.411 & 43.630 \\
\hline
\end{tabular}

\subsubsection{Determination of chloride and calcium contents}

The chloride content $\left(\mathrm{Cl}^{-}\right)$was determined by titration of the filtrate. Silver ion $\left(\mathrm{Ag}^{+}\right)$was used as titrant $\left(0.282 \mathrm{~N} \mathrm{AgNO}_{3}\right.$ solution) and potassium chromate as indicator of the endpoint when an orange-red color was obtained, indicating the presence of silver chromate. The concentration of chloride ions in the filtrate was obtained when $\mathrm{Cl}^{-}>$ $10,000 \mathrm{mg} / \mathrm{L}$, by using Equation (4) (API, 1990).

$\left[\mathrm{Cl}^{-}\right](\mathrm{mg} / \mathrm{L})==\frac{\left[\left(\mathrm{cm}^{3} \text { of } \mathrm{AgNO}^{3}\right) *(1000)\right]}{\left(\mathrm{cm}^{3} \text { of filtrate }\right)}$

Calcium content in the filtrate was obtained by titration with 0.01M EDTA solution using Calcon as indicator. Calcium concentration $(\mathrm{mg} / \mathrm{L})$ was determined using Equation (5) (API, 1990).

Calcium $(\mathrm{mg} / \mathrm{L})=$

$=\left(\mathrm{cm}^{3}\right.$ of EDTA $) *\left(400 / \mathrm{cm}^{3}\right.$ of filtrate $)$

\subsubsection{Cake thickness}

Cake thickness measurements were performed using a Vernier caliper.

\subsubsection{Experimental design}

A $3^{2}$ full factorial design was used to evaluate the influence of calcium and magnesium concentrations in rheological and filtration properties of the developed water-based drilling fluids. Nine formulations of drilling fluids were assayed, all in duplicate, to estimate experimental error, using a synthetic produced water with a different composition, regarding to calcium and magnesium concentrations, as shown in Table 4. The STATISTICA 7.0 software was used to evaluate the influence of the selected factors in the properties of the obtained water-based drilling fluids.

\section{RESULTS AND DISCUSSION}

\subsection{Properties of the water-based drilling fluids}

During the experimental procedure, to formulate the water-based drilling fluid, $\mathrm{NaCl}$ was used as clay swelling inhibitor and thickening agent. A synthetic produced water, with a high content of $\mathrm{NaCl}$, was used in the composition of the drilling fluids. Two water-based drilling fluids were obtained: one using $\mathrm{NaCl}$ as additive (17 $\mathrm{lb} / \mathrm{bbl})$ and the other one without this additive.

Table 5 shows the properties of the obtained drilling fluids. It can observe that the fluid formulated without addition of $\mathrm{NaCl}$ presented similar results for rheology, weight, and $\mathrm{pH}$. However, the filtrate volume was quite smaller, showing that the excess of $\mathrm{NaCl}$ can inhibit the action of filtrate control agents (CMC ADS, and HPA) by means of ion exchange mechanisms. This will result in a high filtrate $(10.5 \mathrm{~mL})$, which causes the formation of a thicker cake, with possibilities to promote complications related to stuck pipe, since the oil well diameter is reduced. The following 
Table 5. Properties of the drilling fluids formulated with and without addition of $\mathrm{NaCl}$ as additive.

\begin{tabular}{lcc}
\hline \multicolumn{1}{c}{ Properties } & Fluid with $\mathrm{NaCl}^{*}$ & Fluid without $\mathrm{NaCl} * *$ \\
\hline Fluid weight (lb/gal) & 10.1 & 9.9 \\
Apparent viscosity (cP) & 22.5 & 22.0 \\
Plastic viscosity (cP) & 18.0 & 16.0 \\
Yield Strength (lbf/100ft ${ }^{2}$ ) & 9.0 & 12.0 \\
Initial gel (lbf/100ft ${ }^{2}$ ) & 4.0 & 4.0 \\
Final gel (lbf/100ft ${ }^{2}$ ) & 5.0 & 5.0 \\
Solid content (\%) & 9.0 & 6.0 \\
Oil content (\%) & 0.0 & 0.0 \\
Filtered (mL) & 10.5 & 4.0 \\
$\mathrm{pH}$ & 8.5 & 8.0 \\
\hline
\end{tabular}

*Fluid with $\mathrm{NaCl}=17.763 \mathrm{lb} \mathrm{NaCl} / \mathrm{bbl} * *$ Fluid without $\mathrm{NaCl}=0.763 \mathrm{lb} \mathrm{NaCl} / \mathrm{bbl}$

Table 6. Properties of the water-based drilling fluids obtained using the synthetic produced water with different concentrations of $\mathrm{Ca}^{2+}$ and $\mathrm{Mg}^{2+}$.

\begin{tabular}{ccccccccccc}
\hline Points & $\begin{array}{c}{[\mathrm{Mg}]} \\
(\mathrm{g} / \mathrm{L})\end{array}$ & $\begin{array}{c}{[\mathrm{Ca}]} \\
(\mathrm{g} / \mathrm{L})\end{array}$ & $\begin{array}{c}\mathrm{iG} \\
\left(\mathrm{lbf} / 100 \mathrm{ft}^{2}\right)\end{array}$ & $\begin{array}{c}\mathrm{fG} \\
\left(\mathrm{lbf} / 100 \mathrm{ft}^{2}\right)\end{array}$ & $\begin{array}{c}\mathrm{AV} \\
(\mathrm{cP})\end{array}$ & $\begin{array}{c}\mathrm{PV} \\
(\mathrm{cP})\end{array}$ & $\begin{array}{c}\mathrm{YP} \\
\left(\mathrm{lbf} / 100 \mathrm{ft}^{2}\right)\end{array}$ & $\begin{array}{c}\text { Filtrate } \\
(\mathrm{mL})\end{array}$ & $\begin{array}{c}{\left[\mathrm{Cl}^{-}\right] \times 0^{3}(\mathrm{mg} / \mathrm{L})} \\
{\left[\mathrm{Ca}^{2+}\right]} \\
\times 10^{3} \\
(\mathrm{mg} / \mathrm{L})\end{array}$ \\
\hline 1 & 0.21 & 22.19 & 4.50 & 5.50 & 22.75 & 16.00 & 13.50 & 8.15 & 94.50 & 6.53 \\
2 & 4.81 & 0.73 & 4.00 & 5.00 & 22.50 & 15.50 & 16.50 & 4.85 & 78.50 & 0.34 \\
3 & 9.41 & 22.19 & 4.00 & 5.00 & 22.50 & 15.00 & 14.00 & 8.40 & 93.00 & 7.51 \\
4 & 0.21 & 0.73 & 4.50 & 5.50 & 25.75 & 16.50 & 18.50 & 4.75 & 83.00 & 0.20 \\
5 & 0.21 & 43.63 & 4.00 & 5.00 & 20.50 & 14.50 & 12.00 & 7.45 & 104.50 & 7.73 \\
6 & 9.41 & 0.73 & 4.50 & 5.50 & 25.25 & 17.00 & 16.50 & 5.75 & 87.00 & 0.64 \\
7 & 4.81 & 22.19 & 4.50 & 5.50 & 23.50 & 16.00 & 15.00 & 7.65 & 91.50 & 7.17 \\
8 & 4.81 & 43.63 & 3.00 & 4.00 & 15.50 & 13.00 & 5.00 & 9.30 & 100.50 & 10.76 \\
9 & 9.41 & 43.63 & 4.50 & 5.50 & 23.25 & 16.00 & 14.50 & 8.60 & 104.50 & 10.24 \\
\hline
\end{tabular}

study will limit the use of additional $\mathrm{NaCl}$ in the formulation of the drilling fluid, resulting in a less expensive fluid.

\subsection{Experimental design}

The objective of the experimental design was to evaluate the influence of calcium and magnesium concentrations in rheological and filtrate properties of the water-based drilling fluids. The Statistica ${ }^{\circledR}$ software (7.0) was used for this purpose. This study considered two factors (calcium and magnesium concentrations) and three levels $(-1,0,+1)$. The maximum concentration levels $(+1)$ for $\mathrm{Mg}(9.411$ $\mathrm{g} / \mathrm{L})$ and $\mathrm{Ca}(43.630 \mathrm{~g} / \mathrm{L})$ were set based on the concentrations of salts found in the produced water from the Urucu oilfield. The minimum levels, (-1), $0.209 \mathrm{~g} / \mathrm{L}$ for $\mathrm{Mg}$ and $0.733 \mathrm{~g} / \mathrm{L}$ for $\mathrm{Ca}$, were fixed based on the salt contents normally added in the water used to formulate water-based drilling fluids. The evaluated responses were rheological properties, filtrate volume, and also chloride content in the filtrate.

Table 6 shows the concentration of calcium and magnesium used in the produced water and the evaluated properties: initial gel (iG), final gel (fG), apparent viscosity (AV), plastic viscosity (PV), yield point (YP), filtrate volume, and chloride and calcium concentrations in the filtrate. Table 7 shows the same results for the fluids after the ageing process.

\subsection{Rheological properties}

The thixotropy is obtained by the difference between the final gel ( $f G$ ) and the initial gel (iG). For all studied fluids, the thixotropy degree was 
Table 7. Properties of the studied water-based drilling fluids after ageing process.

\begin{tabular}{|c|c|c|c|c|c|c|c|c|c|c|}
\hline Points & $\begin{array}{l}{[\mathrm{Mg}]} \\
(\mathrm{g} / \mathrm{L})\end{array}$ & $\begin{array}{l}{[\mathrm{Ca}]} \\
(\mathrm{g} / \mathrm{L})\end{array}$ & $\begin{array}{c}\text { iG } \\
\left(\mathrm{lbf} / 100 \mathrm{ft}^{2}\right)\end{array}$ & $\begin{array}{c}\mathrm{fG} \\
\left(\mathrm{lbf} / 100 \mathrm{ft}^{2}\right)\end{array}$ & $\begin{array}{l}\text { AV } \\
(c P)\end{array}$ & $\begin{array}{l}\text { PV } \\
\text { (cP) }\end{array}$ & $\begin{array}{c}Y P \\
\left(\mathrm{lbf} / 100 \mathrm{ft}^{2}\right)\end{array}$ & $\begin{array}{c}\text { Filtrate } \\
(\mathrm{mL})\end{array}$ & $\begin{array}{c}{\left[\mathrm{Cl}^{-}\right] \mathrm{x}} \\
10^{3}(\mathrm{mg} / \mathrm{L})\end{array}$ & $\begin{array}{c}{\left[\mathrm{Ca}^{2+}\right]} \\
\times 10^{3} \\
(\mathrm{mg} / \mathrm{L})\end{array}$ \\
\hline 1 & 0.21 & 22.19 & 4.00 & 4.50 & 20.50 & 15.00 & 11.00 & 8.10 & 92.50 & 5.91 \\
\hline 2 & 4.81 & 0.73 & 4.00 & 5.00 & 22.75 & 15.50 & 14.50 & 5.85 & 82.50 & 0.76 \\
\hline 3 & 9.41 & 22.19 & 4.00 & 5.00 & 20.75 & 14.50 & 12.50 & 7.50 & 90.50 & 8.26 \\
\hline 4 & 0.21 & 0.73 & 4.00 & 5.00 & 23.00 & 15.50 & 15.00 & 5.70 & 81.50 & 0.14 \\
\hline 5 & 0.21 & 43.63 & 4.00 & 5.00 & 18.75 & 13.00 & 11.50 & 9.85 & 101.50 & 9.71 \\
\hline 6 & 9.41 & 0.73 & 4.50 & 5.50 & 22.25 & 15.00 & 14.50 & 5.70 & 81.00 & 0.44 \\
\hline 7 & 4.81 & 22.19 & 4.00 & 5.00 & 21.00 & 15.00 & 12.00 & 7.80 & 90.50 & 7.37 \\
\hline 8 & 4.81 & 43.63 & 2.50 & 3.50 & 15.25 & 11.00 & 8.50 & 7.10 & 101.50 & 10.12 \\
\hline 9 & 9.41 & 43.63 & 4.00 & 5.00 & 19.75 & 14.00 & 11.50 & 7.60 & 104.50 & 11.28 \\
\hline
\end{tabular}

around 1. This result was also obtained for the fluid formulated with the initial produced water (Table 5 - without addition of $\mathrm{NaCl}, \mathrm{Ca}$, and $\mathrm{Mg}$ ). The thixotropy of all developed fluids was low and the presence of calcium did not change this result.

The apparent viscosity decreased with increasing calcium concentration, both before and after ageing process, impairing the efficiency of the fluid. This effect was observed due a reduction in the efficiency of viscosifying agents (polymers) with increasing calcium concentration.

For plastic viscosity results, it was observed a similar behavior to ones obtained for apparent viscosity, before and after the ageing process. The increase in calcium concentration reduced the plastic viscosity. This occurred because the excess of $\mathrm{Ca}^{+2}$ in water caused the replacement of the $\mathrm{Na}^{+}$ from $\mathrm{CMC}$, resulting in a $\mathrm{CMCCa}^{+2}$ precipitate. This precipitate, once formed, reduced the dispersed particles, causing a reduction in plastic viscosity. This is considered a negative result since once a fluid with low power to transport rock cuttings is obtained drilling operations are damaged.

For the yield point, a reduction in this value was also observed with increasing calcium concentration due to a reduction in interaction forces between dispersed particles. The formation of precipitate will reduce the resistance of the fluid to move, thus, reducing the work necessary for pumping this fluid.

The magnesium concentration range evaluated was smaller than the calcium one and, as observed in Tables 6 and 7, showed no influence on rheological parameters.
The Pareto charts (95\% confidence level) for rheological properties (Table 6) are shown in Figure 1. A statistically significant relationship between calcium and magnesium concentrations with initial gel (Fig. 1a), final gel (Fig. 1b), apparent viscosity (Fig. 1C), and plastic viscosity (Fig 1d) of the developed water-based drilling fluids was not observed. This occurred because the concentration of biopolymer and natural modified polymer in the formulation of the proposed fluids are sufficiently low, resulting in no changes in its functions.

\subsection{Influence of calcium and magnesium concentrations in the filtrate}

From the results for $\left[\mathrm{Ca}^{2+}{ }^{+}\right.$and $\left[\mathrm{Cl}^{-}\right]$in the filtrate, Table 6 , one can observe that the calcium concentration has a direct influence in chloride concentration. This influence does not occur as strongly with the magnesium one, considering that calcium concentration is higher. The Pareto chart (95\% confidence level) for this study is shown in Figure 2.

Figure 2 shows that only the effects of calcium (linear, $p<0.05$,) and magnesium (quadratic, $\mathrm{p}<0.05) \quad$ concentrations were statistically significant. The first one with a positive effect in the response and the second one with a negative effect, respectively. The chloride concentration in the filtrate $\left[\mathrm{Cl}^{-}\right]$can be determined by using Equation (6), obtained considering solely the significant linear and quadratic regression coefficients.

$\left[\mathrm{Cl}^{-}\right](\mathrm{mg} / \mathrm{L})=93,000.71-2,125.00 *[\mathrm{Mg}]^{2}+$ $+10,168.8 *[\mathrm{Ca}]$ 

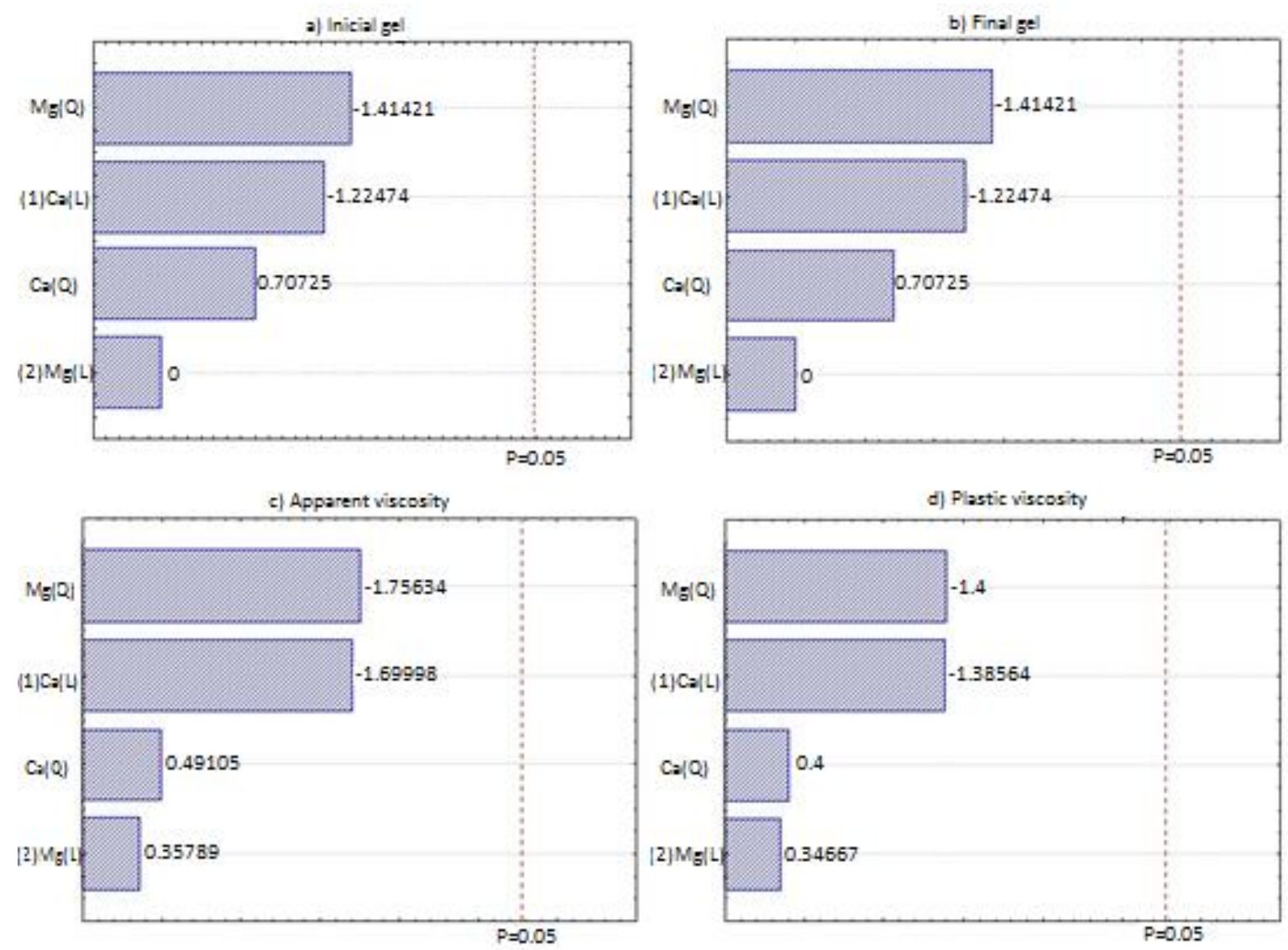

Figure 1. Pareto charts with $95 \%$ confidence level for rheological properties. (a) initial gel; (b) final gel; (c) apparent viscosity; and (d) plastic viscosity.

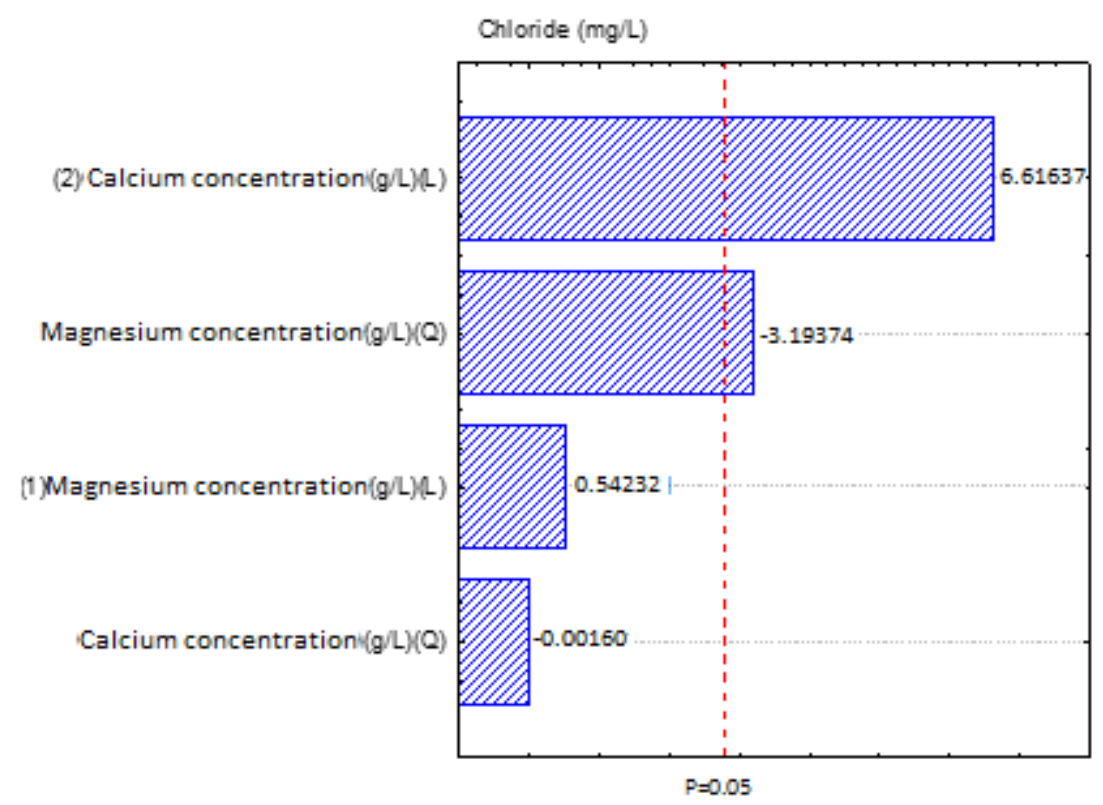

Figure 2. Pareto chart showing the effects of calcium and magnesium concentrations in chloride concentration.

Where $[\mathrm{Mg}]$ and $[\mathrm{Ca}]$ are the initial magnesium and calcium concentrations in the synthetic produced water, respectively (Table 6). For significant effects, the coefficient of determination $\left(R^{2}\right)$ of the statistical model was calculated. Table 8 presents an analysis of variance (ANOVA) for the evaluated 
Table 8. ANOVA for calcium and magnesium concentration influence considering the chloride concentration as response.

\begin{tabular}{lcccccc}
\hline \multicolumn{1}{c}{ Source } & $\begin{array}{c}\text { Sum of } \\
\text { Squares }\left(10^{5}\right)\end{array}$ & $\begin{array}{c}\text { Degrees of } \\
\text { freedom }\end{array}$ & $\begin{array}{c}\text { Mean sum of } \\
\text { squares }\left(10^{5}\right)\end{array}$ & $\mathrm{F}_{\text {calculated }}$ & $\mathrm{F}_{\text {table }}$ & $\mathrm{R}^{2}$ \\
\hline Regression & 6573.33 & 4.0 & 1643.33 & 46.400 & 6.388 & 0.979 \\
Error & 141.67 & 4.0 & 35.42 & & & \\
Total & 6715.00 & 8.0 & & & & \\
\hline
\end{tabular}

response, the chloride concentration $(\mathrm{mg} / \mathrm{L})$, as a function of calcium and magnesium concentration levels.

Table 8 shows that the coefficient of determination obtained for the model was 0.979 . This result indicates that this model well represents the results obtained experimentally. The test of analysis of variance, the $\mathrm{F}$ test, was performed to evaluate if the statistical model is significant or predictive. The $\mathrm{F}$ test considers models as significant when the $F$ value obtained from the regression is higher than the value given by the $\mathrm{F}$ table $\left(F_{\text {calculated }} / F_{\text {table }}>1\right)$. Inversely, the model is considered predictive if the value obtained experimentally is lower than the value given by the F-table $\left(F_{\text {calculated }} / F_{\text {table }}<1\right)$ (Castro Dantas et al.,
2014). Based on the results presented in Table 8 , one can observe that $F_{\text {table }} / F_{\text {calculated }}=6.388 / 46.4=$ 0.138 , showing that the model can be used for predictive purposes within the studied domain.

Figure 3 shows the contour plot for the dependent variable, Chloride concentration $(\mathrm{mg} / \mathrm{L})$, considering the effects of calcium and magnesium concentrations $(\mathrm{g} / \mathrm{L})$. In this figure one can observe that calcium concentrations exceeding $35 \mathrm{~g} / \mathrm{L}$ have a direct influence in increasing chloride concentration. Conversely, an increase in magnesium concentration does not influence chloride concentration.

Calcium chloride and magnesium chloride salts were used in the formulation of the synthetic

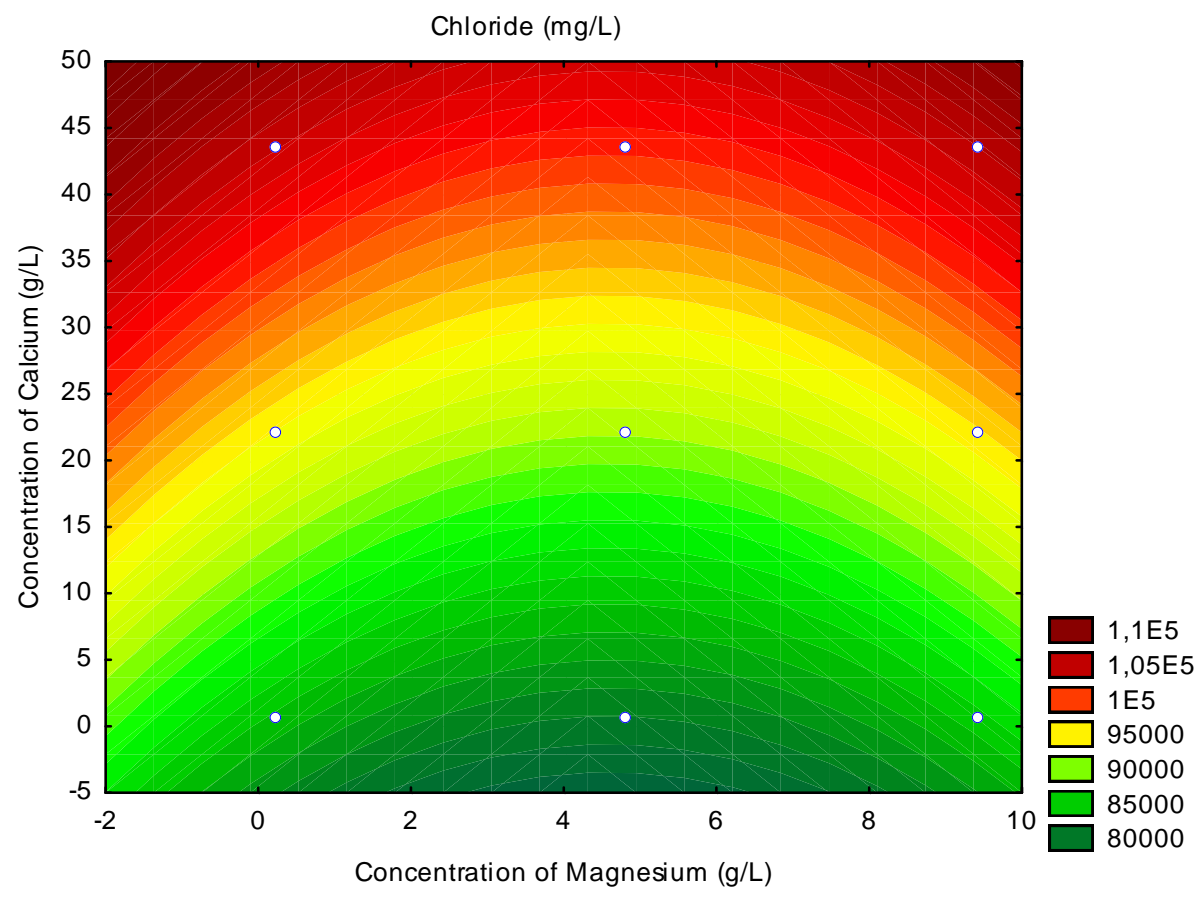

Figure 3. Contour plot showing the effects of calcium $(\mathrm{g} / \mathrm{L})$ and magnesium concentrations $(\mathrm{g} / \mathrm{L})$ in chloride concentration $(\mathrm{mg} / \mathrm{L})$. 
Table 9. Influence of calcium and magnesium concentrations in filtrate volume (mL).

\begin{tabular}{lccccccccc}
\hline \multicolumn{1}{c}{ Data } & 1 & 2 & 3 & 4 & 5 & 6 & 7 & 8 & 9 \\
\hline$[\mathrm{Mg}](\mathrm{g} / \mathrm{L})$ & 0.209 & 4.810 & 9.411 & 0.209 & 0.209 & 9.411 & 4.810 & 4.810 & 9.411 \\
[Ca] $(\mathrm{g} / \mathrm{L})$ & 22.186 & 0.733 & 22.186 & 0.733 & 43.630 & 0.733 & 22.186 & 43.63 & 43.630 \\
Filtrate $(\mathrm{mL})$ & 8.150 & 4.850 & 8.400 & 4.750 & 7.450 & 5.750 & 7.650 & 9.30 & 8.600 \\
\hline
\end{tabular}

produced water. As the calcium concentration was always higher than the magnesium one, the $\mathrm{Ca}^{2+}$ concentration had more influence on the response. With this result, one can conclude that a reaction between chloride ions and fluid additives was not observed.

Table 9 shows the results for filtrate volume $(\mathrm{mL})$ according to calcium and magnesium concentrations in the synthetic produced water. One can observe that only calcium concentration influences the filtrate volume.

Figure 4 shows the Pareto chart, with 95\% confidence level, considering the variations of calcium and magnesium concentrations.

Figure 4 shows that the calcium concentration $(\mathrm{g} / \mathrm{L})$ was statistically significant considering the quadratic interaction $(P<0.05)$, with a positive effect on the filtrate volume $(\mathrm{mL})$. For magnesium concentration $(\mathrm{g} / \mathrm{L})$, both linear and quadratic interactions were not significant. Equation 7 shows the statistical model obtained, considering the significant quadratic regression coefficients.

Filtrate $\left.(\mathrm{mL})=6.356+1.283 *\left[\mathrm{Ca}^{2+}\right]\right)^{2}$

The determination coefficient $\left(R^{2}\right)$ is shown in Table 10, which also presents an analysis of variance (ANOVA) for the filtrate volume $(\mathrm{mL})$ as a function of calcium and magnesium concentration levels.

The determination coefficient was 0.926, showing that the model well describes the obtained results. Based on the results of Table 10, one can observe that the $F$ value from the

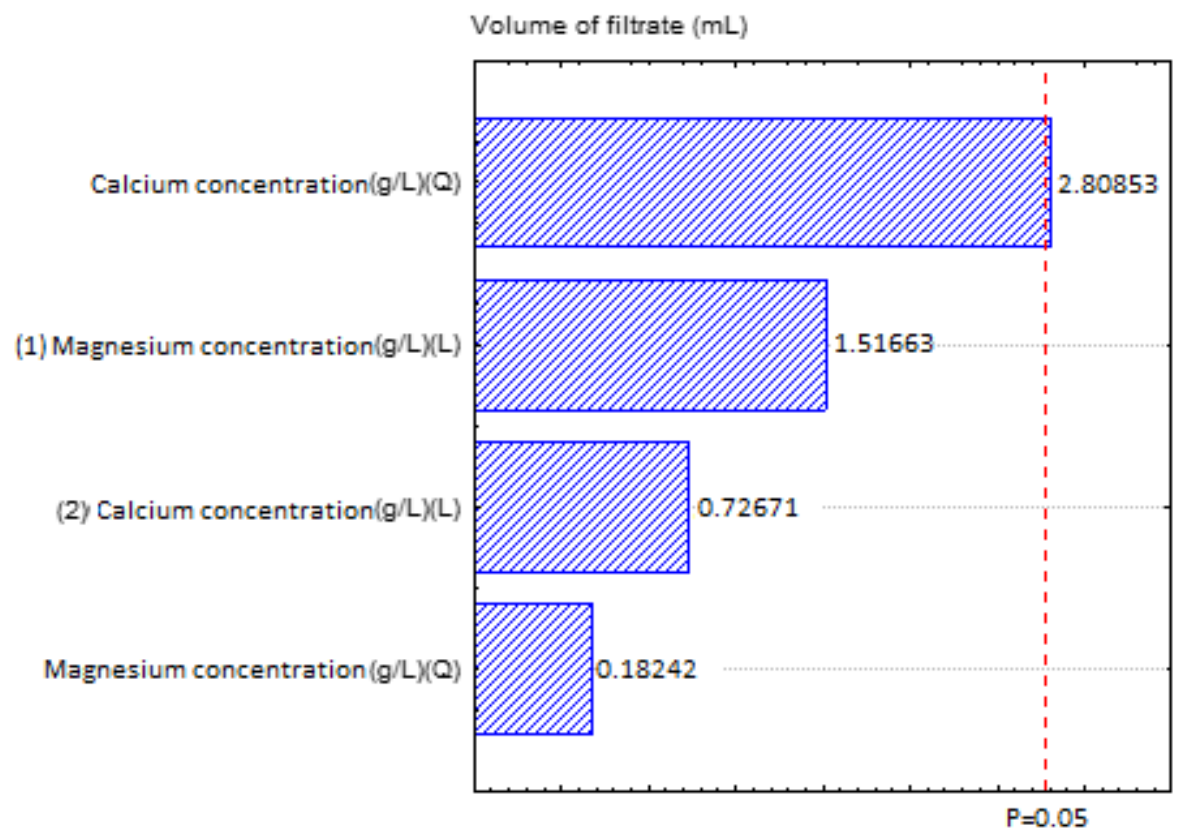

Figure 4. Pareto chart for the effects of calcium and magnesium concentrations in the filtrated volume (mL), with a $95 \%$ confidence level. 
Table 10. Influence of calcium and magnesium concentrations in filtrate volume $(\mathrm{mL})$.

\begin{tabular}{lcccccc}
\hline $\begin{array}{l}\text { Source of } \\
\text { variation }\end{array}$ & $\begin{array}{c}\text { Sum } \\
\text { Quadratic }\left(10^{5}\right)\end{array}$ & $\begin{array}{c}\text { Degrees of } \\
\text { freedom }\end{array}$ & $\begin{array}{c}\text { Mean sum of } \\
\text { squares }\left(10^{5}\right)\end{array}$ & $\mathrm{F}_{\text {calculated }}$ & $\mathrm{F}_{\text {table }}$ & $\mathrm{R}^{2}$ \\
\hline Regression & 20.934 & 4.000 & 5.233 & 12.539 & 6.388 & 0.926 \\
Error & 1.669 & 4.000 & 0.417 & & & \\
Total & 22.604 & 8.000 & & & & \\
\hline
\end{tabular}

regression is higher than the value given by the $F$ table $\left(F_{\text {table }} / F_{\text {calculated }}=6.388 / 12.539=0.509\right)$, showing that the model can be used for predictive purposes within the studied domain.

Figure 5 shows a contour plot for the volume of filtrate $(\mathrm{mL})$, the dependent variable, as a function of calcium $(\mathrm{g} / \mathrm{L})$, and magnesium concentrations $(\mathrm{g} / \mathrm{L})$. It can be observe that calcium concentration has a direct influence in increasing filtrate volume for values above $15 \mathrm{~g} / \mathrm{L}$. Conversely, an increase in magnesium concentration does not influence this parameter. As previously explained, the excess of $\mathrm{Ca}^{+2}$ in water causes the replacement of the $\mathrm{Na}^{+}$ from $\mathrm{CMC}$, resulting in a $\mathrm{CMCCa}^{+2}$ precipitate, thereby increasing the volume of filtrate. It is important to consider that an increase of calcium concentration may reduce the activity of filtrate control agents (CMC, ADS, and PAH), damaging its retention power.
To reduce filtrate invasion into the formation, cake permeability must be kept low. The cumulative volume of filtrate is proportional to the amount of cake deposited. Therefore, high permeability values form a thick cake, reduce the diameter of the well, and cause excessive torque and pipe sticking, among other problems. The cakes formed by fluids 8 and 9 were thicker, reaching $4.5 \mathrm{~mm}$, while the other ones varied between 1.5 and $2 \mathrm{~mm}$.

From a geological point of view, the invasion of large volumes of filtrate in the formation can affect its production capacity, modifying properties such as permeability, porosity, and plasticity.

The water-based drilling fluids obtained using produced waters with the highest concentrations of calcium and magnesium, fluids 8 and 9 , presented unfavorable results in terms of filtrate and rheological properties. Based on these results,

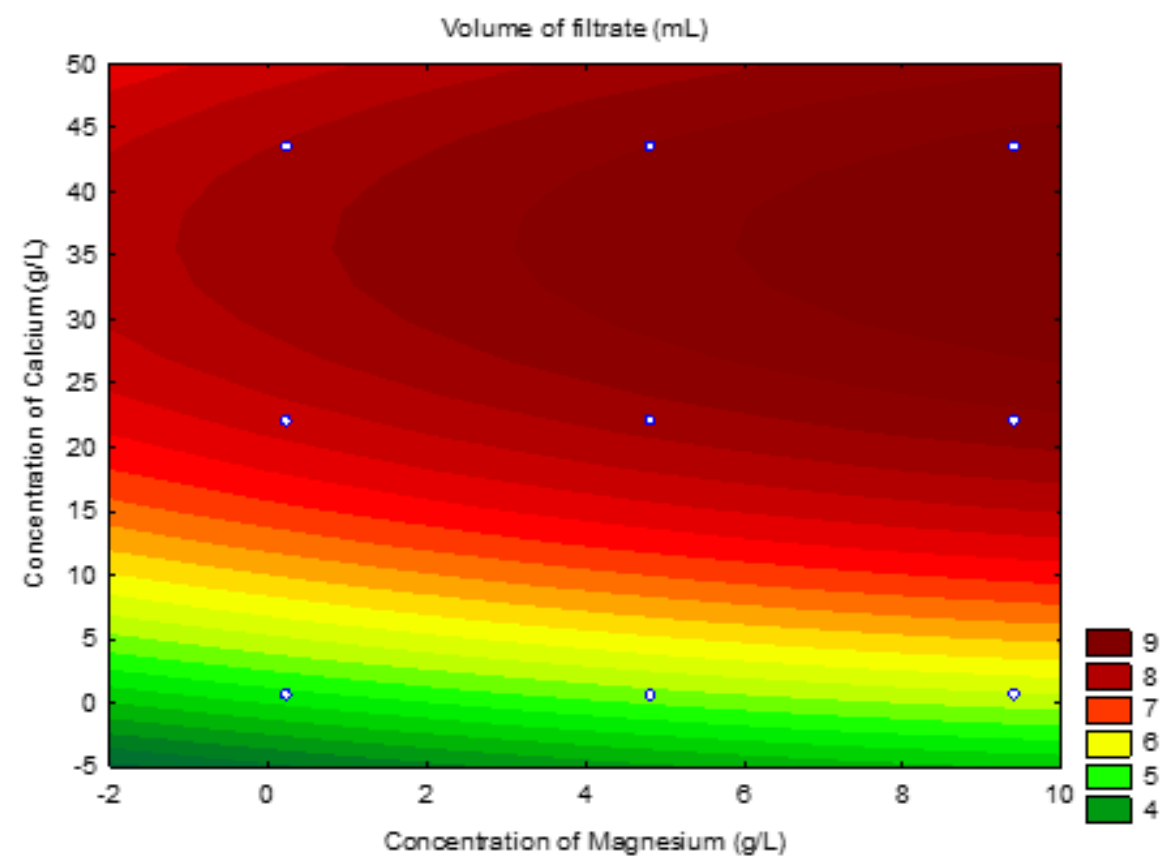

Figure 5. Contour plot showing the effects of calcium $(\mathrm{g} / \mathrm{L})$ and magnesium concentrations $(\mathrm{g} / \mathrm{L})$ in filtrate volume ( $\mathrm{mg} / \mathrm{L})$. 
one can establish that calcium concentration is the determining factor in the formulation of waterbased drilling fluids with good performance.

Fluid 4, with the lowest calcium and magnesium concentrations, showed the best results in the filtrate test (low volume of filtrate). Fluid 2, with the minimum calcium concentration and an average value of magnesium concentration, presented filtrate volume close to the one displayed by fluid 4 . Fluid 6 , with the maximum magnesium concentration and the minimum calcium concentration, presented the volume of filtrate only $1 \mathrm{~mL}$ higher than the value of fluid 4 . Therefore, the magnesium concentration is not a concern in formulating water-based drilling fluids taking advantage of the use of produced water.

\section{CONCLUSIONS}

The study of the development of water-based drilling fluids using synthetic produced water, with characteristics similar to the one produced in Urucu field, allowed us to conclude that:

- It is possible to obtain a fluid with desirable characteristics using different contents of chloride, calcium, and magnesium;

- It is not necessary to add $\mathrm{NaCl}$ to the produced fluid, thereby reducing costs;

- High concentrations of calcium and magnesium lead to undesirable rheological properties, with declines in the values of plastic and apparent viscosities and gel strength (initial and final);

- Fluids with high concentrations of calcium show thicker cake and high filtrate volumes;

- Magnesium concentration is not a significant parameter, with small influence in the rheological results and filtrate;

- Fluids 4 and 6 represent the best composition;

- Produced water with up to $9.411 \mathrm{~g} / \mathrm{L}$ magnesium concentration and $0.733 \mathrm{~g} / \mathrm{L}$ calcium concentration can be used in the formulation of water-based drilling fluid, imparting suitable properties to this product, as presented by fluid 6;
- Finally, this application constitutes a good alternative for the reuse of produced water.

\section{REFERENCES}

AMOCO. Drilling Fluids Manual. Amoco Production Company, 1994.

API. Recommended practice standard procedure for laboratory testing drilling fluids. 1990.

Caenn, R.; Chillingar, G. V. Drilling fluids: State of the art. Journal of Petroleum Science and Engineering, v. 14, p. 221-230, 1996. https://doi.org/10.1016/0920-4105(95)00051-8

Caenn, R.; Darley, H. C. H.; Gray, G. R. Composition and Properties of Drilling and Completion Fluids. V. 6, USA: Gulf Professional Publishing, 2011.

Castro Dantas, T. N.; Dantas Neto, A. A.; Moura, M. C. P. A.; Barros Neto, E. L.; Forte Duarte, K. R. Study of new alternatives for removal of sulfur from diesel. Brazilian Journal of Petroleum and Gas, v. 8(1), p. 015-032, 2014.

http://dx.doi.org/10.5419/bjpg2014-0002

El-Sukkary, M.M.A.; Ghuiba, F.M.; Sayed, G.H.; Abdou, M.I.; Badr, E.A.; Tawfik, S.M.; Negm, N.A. Evaluation of some vanillin-modified polyoxyethylene surfactants as additives for water based mud. Egyptian Journal of Petroleum, v. 23, p. 7-14, 2014. https://doi.org/10.1016/j.ejpe.2014.02.002

Fakhru'I-Razi, A.; Pendashteh, A.; Abdullah, L. C.; Biak, D. R. A.; Madaeni, S. S.; Abidin, Z. Z. Review of technologies for oil and gas produced water treatment. Journal of Hazardous Materials, v. 170, p. 530-551, 2009.

https://doi.org/10.1016/i.jhazmat.2009.05.044

Fink, J. K. Petroleum Engineer's Guide to Oil Field Chemicals and Fluids. v. I, First edition, USA: Gulf Professional Publishing, 2012.

Lake, L. W. Petroleum Engineering Handbook. v. II, U. of Texas at Austin: 2006. 
Menezes, R.R.; Marques, L.N.; Campos, L.A.; Ferreira, H.S.; Santana, L.N.L.; Neves, G.A. Use of statistical design to study the influence of $\mathrm{CMC}$ on the rheological properties of bentonite dispersions for water-based drilling fluids. Applied Clay Science, v. 49, p. 13-20, 2010.

https://doi.org/10.1016/i.clay.2010.03.013

Meng, X.; Zhang, Y.; Zhou, F.; Chu, P. K. Effects of carbon ash on rheological properties of waterbased drilling fluids. Journal of Petroleum Science and Engineering, v. 100, p. 1-8, 2012.

https://doi.org/10.1016/j.petrol.2012.11.011

Nasser, J.; Jesil, A.; Mohiuddin, T.; Ruqeshi, M. Al; Devi, G.; Mohataram, S. Experimental Investigation of Drilling Fluid Performance as Nanoparticles. World Journal of Nano Science and Engineering, v. 3, p. 57-61, 2013.

https://doi.org/10.4236/wjnse.2013.33008

Riley, S. M.; Oliveira, J. M. S.; Regnery, J.; Cath, T. Y. Hybrid Membrane Bio-systems for Sustainable Treatment of Oil \& Gas Produced Water and Frac Flowback. Separation and Purification Technology, v. , p. 1-42, 2016.

Rocha, J. H. B.; Gomes, M. M. S.; Fernandes, N. S.; Silva, D. R.; Martínez-Huitle, C. A. Application of electrochemical oxidation as alternative treatment of produced water generated by Brazilian petrochemical industry. Fuel Processing Technology, v. 96, p. 80-87, 2012. https://doi.org/10.1016/i.fuproc.2011.12.011
Sharghi, E. A. Treatment of hypersaline produced water employing a moderately halophilic bacterial consortium in a membrane bioreactor: Effect of salt concentration on organic removal performance, mixed liquor characteristics and membrane fouling. Bioresourse Technology, v. 164, p. 203-213, 2014.

https://doi.org/10.1016/j.biortech.2014.04.099

Vajargah, A. K.; Oort, E. v. Determination of drilling rheology under downhole conditions by usisng real-time distributed pressure data. Journal of Natural Gas Science and Engineering, v. 24, p. 400-411, 2015.

https://doi.org/10.1016/j.jngse.2015.04.004

Zheng, J.; Chen, B.; Thanyamanta, W.; Hawboldt, K.; Zhang, B.; Liu, B. Offshore produced water management: A review of current practice and challenges in harsh/Arctic environments. Marine Pollution Bulletin, v. 104, p. 7-19, 2016. https://doi.org/10.1016/j.marpolbul.2016.01.004

Zhuang, G.; Zhang, Z.; Fu, M.; Ye, X.; Liao, L. Comparative study on the use of cationic-nonionicorgano-montmorillonite in oil-based drilling fluids. Applied Clay Science, v. 116-117, p. 257-262, 2015. https://doi.org/10.1016/i.clay.2015.04.004 